\title{
Penerapan Model Pembelajaran Word Square untuk Meningkatkan Motivasi Belajar Siswa pada Tema Makanan Sehat Di Kelas V B SD Negeri 121/IX Jerambah Bolong
}

\author{
Mardiana \\ SD N 121/IX Jerambah Bolong \\ Correspondence email: mard8792@gmail.com
}

\begin{abstract}
Penelitian ini dilatarbelakangi oleh motivasi belajar siswa yang masih rendah sehingga menyebabkan hasil belajar siswa menjadi rendah pula. Tujuan penelitian ini adalah untuk mendapatkan informasi dan membahas tentang penerapan model pembelajaran word square untuk meningkatkan motivasi belajar siswa pada tema makanan sehat di kelas V B SD Negeri 121/IX Jerambah Bolong pada tahun ajaran 2018/2019. Jenis penelitian ini adalah penelitian tindakan kelas yang terdiri dari dua siklus dimana masing-maisng siklus mengikuti empat tahapan yaitu perencanaan, pelaksanaan, observasi dan refleksi. Maisng-masing siklus terdiri dari dua kali pertemuan. Penelitian ini dilaksanakan di SD Negeri 121/IX Jerambah Bolong pada tahun ajaran 2018/2019 dengan subjek penelitian siswa kelas V SD Negeri 121/IX Jerambah Bolong yang terdiri dari 24 orang siswa yang terdiri dari 14 orang laki-laki dan 10 orang perempuan. Teknik pengumpulan data menggunakan lembar observasi, tes, catatan lapangan dan dokumentasi. Data dianalisis menggunakan persentase dan reduksi data. Hasil penelitian menunjukkan bahwa melalui penerapan model pembelajaran word square dapat meningkatkan motivasi belajar siswa pada tema makanan sehat di kelas V B SD Negeri 121/IX Jerambah Bolong pada tahun ajaran 2018/2019 dengan tindakan memberikan pujian.
\end{abstract}

Kata Kunci: Motivasi belajar, Word square

\begin{abstract}
This study is motivated by low student learning motivation that causes students' learning outcomes to be low as well. The purpose of this research is to obtain information and discuss about the application of word square learning model to increase students' learning motivation on the theme of healthy food in grade V B of SD Negeri 121/IX Jerambah Bolong in the 2018/2019 school year. This type of research is a class action research consisting of two cycles in which each cycle follows four stages, namely planning, implementation, observation and reflection. Each cycle consists of two meetings. This research was conducted at SD Negeri 121/IX Jerambah Bolong in the 2018/2019 school year with the subject of research of grade V students of SD Negeri 121/IX Jerambah Bolong consisting of 24 students consisting of 14 men and 10 women. Data collection techniques using observation sheets, tests, field records and documentation. The data is analyzed using percentage and data reduction. The results showed that through the application of word square learning model can increase students' learning motivation on the theme of healthy food in grade V B of SD Negeri 121/IX Jerambah Bolong in the 2018/2019 school year by giving praise.
\end{abstract}

Keywords: Motivation to learn, Word square

\section{PENDAHULUAN}

Pendidikan menurut Undang-undang No. 20 Tahun 2003 tentang Sistem Pendidikan Nasional menyebutkan bahwa Pendidikan adalah usaha sadar dan terencana untuk mewujudkan suasana belajar dan proses pembelajaran agar peserta didik secara aktif mengembangkan potensi dirinya untuk memiliki kekuatan spiritual keagamaan, pengendalian diri, kepribadian, kecerdasan, akhlak mulia, serta keterampilan yang di perlukan dirinya, masyarakat, bangsa dan negara.

Menghadapi tuntutan situasi perkembangan zaman dan pembangunan nasional. Sistem pembangunan, sistem pendidikan nasional harus dapat dilaksanakan secara tepat guna dalam berbagai aspek, dimensi, jenjang, dan tingkat pendidikan. Keadaan semacam itu pada gilirannya akan menuntut para pelaksana dalam bidang pendidikan diberbagai jenjang untuk mampu menjawab tuntutan tersebut melalui fungsinya sebagai guru. Guru merupakan ujung tombak yang berada pada garis terdepan yang langsung berhadapan dengan siswa.

Siswa adalah salah satu komponen manusiawi yang menempati posisi sentral dalam proses pembelajaran. Di dalam proses pembelajaran, siswa sebagai pihak yang ingin meraih cita-cita, memiliki tujuan dan kemudian ingin mencapainya secara optimal. Siswa akan menjadi factor penentu, sehingga menuntut dan dapat mempengaruhi segala sesuatu yang diperlukan untuk mencapai tujuan belajarnya. Jadi dalam proses pembelajaran yang diperhatikan pertama kali adalah siswa.

Dalam rangka peningkatan mutu pendidikan dan kualitas pembelajaran, mulai tahun pelajaran 2013/2014 secara bertahap pemerintah telah memberlakukan kurikulum baru yaitu kurikulum 2013. Strategi pelaksanaan kegiatan belajar siswa SD yang dikehendaki sesuai kurikulum 2013 adalah dengan menerapkan pendekatan saintifik. 
Mardiana, Penerapan Model Pembelajaran Word Square untuk Meningkatkan Motivasi Belajar Siswa pada Tema Makanan Sehat Di Kelas V B SD Negeri 121/IX Jerambah Bolong

Kemendikbud (2013: 4) menyatakan bahwa kurikulum 2013 menekankan pada dimensi pedagogik modern dalam pembelajaran, yaitu menggunakan pendekatan saintifik/ilmiah.

Motivasi belajar merupakan salah satu faktor yang turut menentukan keefektifan dalam pembelajaran. Seorang peserta didik akan belajar dengan baik apabila ada faktor pendorongnya yaitu motivasi belajar. Peserta didik akan belajar dengan sungguh-sungguh jika memiliki motivasi belajar yang tinggi. Menurut Hamzah B. Uno (2011: 23) "motivasi belajar adalah dorongan internal dan eksternal pada siswa yang sedang belajar untuk mengadakan tingkah laku, pada umumnya dengan beberapa indikator atau unsur-unsur yang mendukung. Indikator-indikator tersebut, antara lain: adanya hasrat dan keinginan berhasil, dorongan dan kebutuhan dalam belajar, harapan dan cita-cita masa depan, penghargaan dalam belajar, dan lingkungan belajar yang kondusif."

Motivasi merupakan keadaan dalam diri individu atau organisme yang mendorong perilaku ke arah tujuan. Dengan demikikan dapat dikemukakan bahwa motivasi mempunyai 3 aspek, yaitu (1) keadaan terdorong dalamdiri organisme yaitu kesiapan bergerak karena kebutuhan misalnya kebutuhan jasmani, karena keadaan lingkungan, atau karena keadaan mental seperti berfikir dan ingatan; (2) perilaku yang timbul dan terarah karena keadaan diri; (3) goal atau tujuan yang dituju oleh perilaku tersebut (Bimo Walgito, 2010:241).

Sedangkan menurut Sardiman A. M (2010: 75) dalam kegiatan belajar motivasi dapat dikatakan sebagai keseluruhan daya penggerak di dalam diri siswa yang menimbulkan kegiatan belajar, sehingga tujuan yang dikehendaki oleh subjek belajar itu dapat tercapai. Menurut M. Dalyono (2009: 57) motivasi belajar adalah suatu daya penggerak atau dorongan yang dimiliki oleh manusia untuk melakukan suatu pekerjaan yaitu belajar.

Motivasi belajar ini mempunyai peranan besar dalam keberhasilan seseorang dalam belajar. Berdasarkan uraian tersebut dapat disimpulkan pengertian motivasi belajar yaitu keseluruhan daya penggerak atau dorongan di dalam diri siswa untuk melakukan kegiatan belajar yang ditandai perubahan energi untuk mencapai tujuan yang dikehendaki. Dari beberapa pendapat di atas dapat disimpulkan bahwa motivasi belajar adalah seluruh daya penggerak psikis yang ada dalam diri individu siswa yang dapat memberikan dorongan untuk belajar demi mencapai tujuan dari belajar tersebut.

Model pembelajaran merupakan bagian dari proses pembelajaran yangharus dipersiapkan dan dilakukan oleh guru dalam kegiatan pembelajaran. Hal ini dikarenakan guru sebagai penentu keberhasilan kegiatan pembelajaran di sekolah yang terlibat secara langsung dalam menyusun rencana pembelajaran, mengatur materi peserta didik, dan settingpengajaran. Oleh karena itu setiap model pembelajaran yang akan diterapkan, guru juga harus mempersiapkan perangkat pembelajaran yang akan digunakan.

Menurut Trianto (2014:53) "Model pembelajaran adalah kerangka konseptual yang melukiskan prosedur sistematik dalam mengorganisasikan pengalaman belajar untuk mencapai tujuan belajar tertentu dan berfungsi sebagai pedoman bagi perancang dan melaksanakan pembelajaran". Menurut Arends (dalam Trianto, 2014:51) "Model pembelajaran adalah suatu perencanaan atau suatu pola yang digunakan sebagai pedoman dalam merencanakan pembelajaran di kelas atau pembelajaran dalam tutorial".

Pembelajaran Word Square adalah proses belajar secara induktif, berpusat pada siswa dan berorientasi pada aktivitas refleksi secara personal tentang pemahaman siswa terhadap materi pelajaran yang dipelajari dalam suatu pokok bahasan, dengan memanfaatkan soal-soal dan lembar jawaban yang dikombinasikan dengan kotak-kotak jawaban sebagai alat untuk menjawab soal. Mujiman (2007:140) mengatakan: "Model pembelajaran Word Square merupakan model pembelajaran yang memadukan kemampuan menjawab pertanyaan dengan kejelian dalam mencocokan jawaban pada kotak-kotak jawaban". Jadi, dengan menggunakan model pembelajaran ini, siswa dimungkinkan untuk aktif dalam proses belajar dengan cara menjawab pertanyaan-pertanyaan melalui kotak-kotak jawaban, sekaligus model ini bermanfaat pula untuk melatih kejelian dan ketelitian siswa.

Salah satu alternatif strategi yang dapat meningkatkan motivasi belajar siswa adalah strategi pembelajaran Word Square. Kamulyan dan Risminawati (2012: 71) menjelaskan bahwa strategi Word Square merupakan kegiatan belajar mengajar dimana siswa dihadapkan pada permainan yang menggunakan kartu sebagai media. Kelebihan dari strategi Word Square yaitu: dapat meningkatkan kecerdasan anak dalam merangkai kata yang berserak dalam satu kotak, dimana anak diminta untuk menghubungkan huruf dengan cepat, baik secara menurun atau mendatar. Selain itu, diantaranya: 1) Kegiatan tersebut mendorong pemahaman siswa terhadap materi pelajaran, 2) Melatih untuk berdisiplin, 3) Dapat melatih sikap teliti dan kritis, 4) Merangsang siswa untuk berpikir efektif.

Trianto (2010:87) mengatakan: "Model Word Square merupakan model pembelajaran yang memadukan kemampuan menjawab pertanyaan dengan kejelian dalam mencocokan jawaban pada kotak-kotak jawaban". Mirip seperti mengisi Teka-Teki Silang tetapi bedanya jawabannya sudah ada namun disamarkan dengan menambahkan kotak tambahan dengan sembarang huruf/angka penyamar atau pengecoh. Dengan demikian, dapat disimpulkan bahwa model Word Square merupakan model pembelajaran yang menjadikan soal, lembar jawaban dan kotak-kotak jawaban sebagai alat utama kegiatan belajar. Di dalam kotak tersebut disediakan pula huruf-huruf lain untuk dijadikan sebagai pengecoh guna melatih siswa untuk teliti dan jeli. 


\section{METODE}

Jenis penelitian ini adalah penelitian tindakan kelas yang terdiri dari dua siklus dimana masing-maisng siklus mengikuti empat tahapan yaitu perencanaan, pelaksanaan, observasi dan refleksi. Maisng-masing siklus terdiri dari dua kali pertemuan. Penelitian ini dilaksanakan di SD Negeri 121/IX Jerambah Bolong pada thun ajaran 2018/2019 dengan subjek penelitian siswa kelas V SD Negeri 121/IX Jerambah Bolong yang terdiri dari 24 orang siswa yang terdiri dari 14 orang laki-laki dan 10 orang perempuan. Teknik pengumpulan data menggunakan lembar observasi, tes, catatan lapangan dan dokumentasi. Data dianalisis menggunakan persentase dan reduksi data

\section{HASIL DAN PEMBAHASAN \\ Siklus I \\ Perencanaan}

Tahap perencanaan pada siklus I terdiri dari: 1) menyiapkan perangkat pembelajaran berupa RPP dan silabus, 2) menyiapkan media pembelajaran, 3) mengatur jadwal penelitian, 4) menyiapkan instrument penilaian.

\section{Pelaksanaan}

Penelitian siklus I terdiri dari dua kali pertemuan. Pertemuan pertama dilaksanakan pada hari Senin Tanggal 8 Oktober Tahun 2018 dan pertemuan kedua dilaksanakan pada hari Rabu Tanggal 10 Oktober tahun 2018. Masingmasing pertemun membahas tema makanan sehat. Masing-masing pertemuan terdiri dari tiga kegiatan yaitu pendahuluan, inti, dan penutup. Pada siklus I, peneliti meneraokan model pembelajaran word square. Model pembelajaran ini sebagai pendorong dan penguat siswa terhadap materi yang disampaikan. Guru melatih ketelitian dan ketetapan dalam menjawab dan mencari jawaban mana yang paling tepat melalui model word square tersebut. Guru menyiapkan materi sesuai dengan kompetensi dengan memberikan motivasi kepada siswa. Guru menerangkan materi yang telah disiapkan. Guru membagi beberapa kelompok dalam pembelajaran. Guru membagikan lembar kerja berupa soal dan jawaban di dalam kotak yang terdapat banyak huruf yang teracak. Siswa diperintahkan untuk mengerjakan dan menjawab soal kemudian melingkari huruf dalam kotak sesuai jawaban secara vertikal, horizontal maupun diagonal. Berikan poin pada setiap jawaban yang benar dalam kotak.

\section{Observasi}

Setelah tahap pelaksanaan, berikut akan dijelaskan hasil observasi atau pengamatan peneliti bersama observer selama siklus I. Untuk melihat motivasi belajar siswa selama siklus I dapat dilihat pada tabel berikut ini:

Tabel 1. Motivasi belajar siswa siklus I

\begin{tabular}{llrr}
\hline No & Indikator Motivasi Belajar & Jumlah & Persentase \\
\hline 1 & antusias siswa dalam menerima pembelajaran & 10 & 41.67 \\
2 & kemauan mendengarkan penjelasan dari guru & 13 & 54.17 \\
3 & keberanian menjawab pertanyaan dari guru atau siswa lain & 16 & 66.67 \\
4 & kemauan mengerjakan soal latihan yang diberikan oleh guru & 15 & 62.50 \\
\hline
\end{tabular}

Berdasarkan tabel di atas dapat disimpulkan bahwa penerapan strategi pembelajaran Word Square berjalan dengan cukup baik dan dapat meningkatkan motivasi belajarsiswa dengan perincianindikator sebagai berikut : 1)antusias siswa dalam menerima pembelajaran adalah 10 anak $(41,67 \%), 2)$ kemauan mendengarkan penjelasan dari guru 13 anak (54,17\%), keberanian menjawab pertanyaan dari guru atau siswa lain 16 anak (66,67\%), kemauan mengerjakan soal latihan yang diberikan oleh guru 15 anak (62.50\%). Untuk itu dapat disimpulkan bahwa melalui model pembelajaran word square dapat meingkatkan motivasi belajar siswa yang dilihat dari 4 indikator penilaian, walaupun demikian hasil yang didapat pada siklus I masih belum mencapai target yang ditetapkan. Untuk itu perlu adanya perbaikan-perbaikan pada siklus berikutnya agar motivasi belajar siswa meningkat.

\section{Refleksi}

Tahap refleksi siklus I dilaksanakan pada hari Sabtu Tanggal 13 Oktober tahun 2018 yang dibantu oleh seorang observer yang bernama Nurhasanah, S.Pd dan bertempat di ruangan majelis guru SD Negeri 121/IX Jerambah Bolong. Pada tahap ini peneliti dan observer membahas kendala-kendala yang dihadapi selama siklus I dan mendiskusikan solusi untuk siklus berikutnya. Pada siklus I, masih terdapat siswa yang tidak focus atau bermain-main dalam belajar dan ada juga siswa yang mengganggu siswa lain. Selain itu, guru juga perlu untuk lebih bisa memanfaatkan alokasi waktu yang tersedia agar tujuan pembelajaran tercapai. Untuk itu, pada siklus selanjutnya peneliti dan observer 
berusaha untuk mengatasi masalah tersebut dan pada siklus selanjutnya siswa yang motivasi belajarnya baik dan hasil belajarnya juga baik maka akan dapat reward. Untuk itu penelitian ini dilanjutkan ke siklus berikutnya.

\section{Siklus II \\ Perencanaan}

Tahap perencanaan pada siklus II terdiri dari; 1) guru menyiapkan RPP dan silabus, 2) menyiapan media pembelajaran, 3) mengatur jadwal penelitian, dan 4) menyusun instrument penilaian.

\section{Pelaksanaan}

Tahap pelaksanaan siklus II terdiri dari dua kali pertemuan dimana masing-masing pertemuan terdiri dari tiga kegiatan yaitu pendahuluan, inti, dan penutup. pertemuan pertama dilaksanakan pada hari Senin Tanggal 15 Oktober tahun 2018 dan pertemuan kedua dilaksanakan pada hari Rabu tanggal 17 Oktober tahun 2018 dengan tema makanan sehat. Pada siklus II peneliti melakukan tindakan penelitian sama halnya dengan siklus I dengan meggunakan model pembelajaran word square. Sebelum siswa melakukan kegiatan belajar menjawab pertanyaan dengan memanfaatkan lembar dan kotak-kotak jawaban, guru perlu untuk menjelaskan materi pelajaran secara lengkap sesuai dengan kompetensi yang ingin dicapai. Penjelasan ini merupakan bentuk transfer pengetahuan atau informasi yang diberikan guru kepada siswa, sehingga menjadikan siswa yang tadinya tidak mengetahui menjadi mengetahui, dan yang sebelumnya tidak memahami menjadi memahami. Setelah menjelaskan materi pelajaran, guru kemudian membagikan lembar kegiatan belajar kepada siswa. Lembar tersebut adalah lembar pertanyaan dan jawaban serta lembar yang berisikan kotak-kotak jawaban yang akan digunakan oleh siswa untuk merangkai huruf-huruf menjadi jawaban. Siswa ditugaskan untuk membaca setiap pertanyaan dengan teliti dan cermat dan kemudian memberikan jawaban pada setiap pertanyaan yang diberikan. Ketepatan dalam menjawab setiap pertanyaan akan memudahkan siswa dalam mengisi atau mengarsir huruf-huruf yang ada pada lembar kotak-kotak jawaban. Siswa kemudian mengarsir huruf-huruf yang ada pada kotak jawaban sesuai dengan jawaban yang diberikan. Setiap huruf yang diarsir akan membentuk sebuah kata atau kalimat yang sesuai dengan jawaban yang diberikan. Jika jawaban yang diberikan salah, kemungkinan besar huruf-huruf tersebut tidak ada pada kotak-kotak tersebut. Siswa bersama guru melakukan pemeriksaan terhadap jawaban dan kecocokannya dengan kotak jawaban. Guru mengarahkan siswa untuk saling menukar lembar kerja dengan siswa lainnya, untuk mencegah terjadinya kecurangan pada saat pemeriksaan. Kegiatan pembelajaran diakhiri dengan melakukan penarikan kesimpulan terhadap materi pelajaran, untuk meluruskan pemahaman siswa terhadap materi pelajaran. Setiap hasil pekerjaan siswa yang telah selesai diperiksa, dinilai oleh guru sesuai dengan berapa jumlah jawaban yang benar dan dimasukkan ke dalam daftar nilai siswa.

\section{Observasi}

Setelah tahap pelaksanaan, berikut akan dijelaskan hasil observasi atau pengamatan peneliti bersama observer selama siklus II. Untuk melihat motivasi belajar siswa selama siklus II dapat dilihat pada tabel berikut ini:

Tabel 2. Motivasi belajar siswa siklus II

\begin{tabular}{llrr}
\hline No & Indikator Motivasi Belajar & Jumlah & Persentase \\
\hline 1 & antusias siswa dalam menerima pembelajaran & 19 & 79.17 \\
2 & kemauan mendengarkan penjelasan dari guru & 20 & 83.33 \\
3 & keberanian menjawab pertanyaan dari guru atau siswa lain & 22 & 91.67 \\
4 & kemauan mengerjakan soal latihan yang diberikan oleh guru & 21 & 87.50 \\
\hline
\end{tabular}

Berdasarkan tabel di atas dapat disimpulkan bahwa penerapan strategi pembelajaran Word Square berjalan dengan sangat baik dan dapat meningkatkan motivasi belajarsiswa dengan perincianindikator sebagai berikut : 1)antusias siswa dalam menerima pembelajaran adalah 19 anak $(79,17 \%), 2)$ kemauan mendengarkan penjelasan dari guru 20 anak (83,33\%), keberanian menjawab pertanyaan dari guru atau siswa lain 22 anak (91,67\%), kemauan mengerjakan soal latihan yang diberikan oleh guru 21 anak (87.50\%). Untuk itu dapat disimpulkan bahwa melalui model pembelajaran word square dapat meingkatkan motivasi belajar siswa yang dilihat dari 4 indikator penilaian.

\section{Refleksi}

Tahap refleksi siklus II dilaksanakan pada hari Sabtu tanggal 20 Oktober tahun 2018 yang dibantu oleh seorang observer yang bernama Nurhasanah, S.Pd dan bertempat di rungan kelas V B SD Negeri 121/IX Jerambah Bolong. Pada tahap ini di dapat hasil diskusi antara peneliti dan observer bahwa kendala-kendala yang didapat selama siklus I dapat teratasi pada siklus II. Hal ini dapat dilihat peningkatan motivasi belajar siswa dan hasil belajar siswa juga meningkat. Hal ini juga dengan adanya tidakan pemberian reward. Untuk itu, penelitian ini tidak dilanjutkan ke siklus berikutya. 


\section{Pembahasan}

Model pembelajaran word square berbantu media gambar. Siswa menjadi lebih aktif dan antusias dalam proses pembelajaran karena disetiap pembelajaran siswa dituntut untuk mengerjakan soal yang diberikan oleh guru dengan mengarsir kotak-kotak yang telah disediakan. Dengan model pembelajaran word square siswa lebih aktif dan juga melatih siswa dalam berpikir kreatif untuk menemukan hubungan-hubungan baru antara berbagai hal karena model pembelajaran ini seperti permainan mengisi teka-teki silang. Suasana yang terjadi dalam proses pembelajaran pun lebih kondusif dan menyenangkan sehingga siswa menjadi lebih mudah menerima palajaran yang diberikan, dikelas eksperimen yang menerapkan model pembelajaran word square berbantu media gambar ini siswa dilatih untuk berfikir lebih teliti dan kritis, serta melatih mereka untuk mampu menganalisa gambar-gambar karena dibantu dengan media gambar yang disediakan oleh guru. Dengan model pembelajaran word square berbantu media gambar ini siswa menjadi aktif dan pembelajaran pun terasa menjadi lebih menyenangkan dan siswa tidak mudah bosan, namun tetap mencapai tujuan pembelajaran.

\section{SIMPULAN}

Hasil penelitian menunjukkan bahwa melalui penerapan model pembelajaran word square dapat meningkatkan motivasi belajar siswa pada tema makanan sehat di kelas V B SD Negeri 121/IX Jerambah Bolong pada thun ajaran 2018/2019 dengan tindakan memberikan pujian.

\section{DAFTAR PUSTAKA}

A.M, Sardiman. 2010. Interaksi dan Motivasi Belajar Mengajar. Jakarta: Rajawali Pers

Dalyono, M. 2009. Psikologi Pendidikan. Jakarta. Rineka Cipta.

Hamzah B. Uno. 2011. Teori Motivasi dan Pengukurannya: Analisis di Bidang Pendidikan. Jakarta: Bumi aksara

Kamulyan, Mulyadi Sri dan Risminawati. 2012. Model-model Pembelajaran Inovatif di Sekolah Dasar. Surakarta: FKIP UMS.

Trianto. 2010. Model Pembelajaran Terpadu, Konsep, Strategi dan Implementasinya dalam KTSP. Jakarta: Bumi Aksara.

Trianto. 2014. Model Pembelajaran Terpadu: Konsep, Strategi, dan Implementasinya dalam Kurikulum Tingkat Satuan Pendidikan (KTSP). Jakarta. Bumi Aksara.

Undang-undang No. 20 Tahun 2003 tentang Sistem Pendidikan Nasional 